Published in final edited form as:

Fertil Steril. 2014 February ; 101(2): 323-329. doi:10.1016/j.fertnstert.2013.12.022.

\title{
AROMATASE DEFICIENCY
}

\author{
Serdar E. Bulun \\ Departments of Obstetrics and Gynecology, Northwestern University, Chicago, Illinois
}

\begin{abstract}
Studies on the phenotypes of women and men with mutations disrupting estrogen biosynthesis and action significantly advanced our knowledge of the physiologic roles of estrogen in humans. Aromatase deficiency results from autosomal recessive inheritance of mutations in the CYP19A1 gene. It gives rise to ambiguous genitalia in $46, \mathrm{XX}$ fetuses. At puberty, affected girls have hypergonadotropic hypogonadism, do not develop secondary sexual characteristics, and exhibit progressive virilization. The affected 46,XY men have normal male sexual differentiation and pubertal maturation. These men, however, are extremely tall and have eunucoid proportions with continued linear growth into adulthood, severely delayed epiphyseal closure and osteoporosis due to estrogen deficiency. Although estrogen was shown to be essential for normal sperm production and function in mice, its role in fertility is not clear in men. Thus far, one estrogen resistant man and one woman with mutations in the estrogen receptor-a (ESR1) gene have been described. Their clinical presentations are similar to that of aromatase deficient men and women.
\end{abstract}

\section{Keywords}

Aromatase deficiency; estrogen resistance; estrogen receptor-alpha; mutation

\section{Introduction}

The physiologic roles of estrogens in women include development of secondary sexual characteristics, regulation of gonadotropin secretion for ovulation, preparation of the uterine, breast and possibly other tissues for progesterone response, maintenance of bone mass, regulation of lipoprotein synthesis, prevention of urogenital atrophy and possibly regulation of insulin responsiveness and maintenance of cognitive function(1). The key physiologic roles of estrogens in men were largely unanticipated until 1994 when estrogen was found to be necessary for fusion of epiphyses and prevention of bone loss $(2,3)$. Since 1994, our understanding of the physiologic roles of estrogen in mice and humans has improved drastically upon the discovery of men and women with mutations in the CYP19AI (aromatase) and ESRI (estrogen receptor-a, ERa) genes and generation of knock-out mice with selective disruptions of these genes(3-10). Consequences of the mutations in the aromatase gene in many adults and children and a mutant ERa gene in a man and a woman will be discussed in this review.

\footnotetext{
(C) 2013 American Society for Reproductive Medicine. Published by Elsevier Inc. All rights reserved.

Correspondence to: Serdar E. Bulun, M.D., Department of Obstetrics and Gynecology, 250 E. Superior Street, Suite 3206, Chicago, IL 60611, Phone: (312) 472-3636, s-bulun@ northwestern.edu.

Publisher's Disclaimer: This is a PDF file of an unedited manuscript that has been accepted for publication. As a service to our customers we are providing this early version of the manuscript. The manuscript will undergo copyediting, typesetting, and review of the resulting proof before it is published in its final citable form. Please note that during the production process errors may be discovered which could affect the content, and all legal disclaimers that apply to the journal pertain.
} 
Until early 1990's, aromatase deficiency had been considered incompatible with life. Following the first description in 1991 of a Japanese newborn girl with an aromatase gene defect, there have been numerous reports in the world literature describing aromatase deficiency $(4,5)$. Thus far, a number of newborn girls and boys, older children including adolescents, and adults with aromatase gene defects were described in detail(4, 6, 7, 11-15). Convincingly, estrogen formation in these patients was virtually absent giving rise to a number of anticipated as well as previously unanticipated symptoms. We know now that aromatase deficiency is an autosomal recessive condition manifest in 46,XX fetuses by female pseudohermaphroditism, and in the case of adult men, tall stature with eunocoid proportions due to unfused epiphyses. In fact, the essential role of estrogen as a determinant of height and bone mass was understood for the first time after the description of estrogenresistant or aromatase-deficient men. $(7,15)$ In the majority of aromatase deficient patients, transient maternal virilization during pregnancy was reported or documented. In fact, maternal virilization during the pregnancy was the key clue that led to the genetic diagnosis of aromatase deficiency in one asymptomatic newborn boy.(13) In utero virilization of $46, \mathrm{XX}$ spotted hyenas constitute a natural animal model to explain some but not all of the mechanisms giving rise to genital ambiguity in newborn girls who are affected by aromatase deficiency.(16) Intriguingly, studying aromatase-deficient men confirmed and extended the conclusions drawn from an estrogen-resistant man regarding the role of estrogen action in men. $(2,3,7,15)$

In addition to the physiologic roles of estrogen summarized above, this steroid is also important regulating glucose metabolism and libido at least in men. The estrogen resistant man and aromatase-deficient men were reported to have glucose intolerance. $(2,17)$ Estrogen replacement in aromatase-deficient men improved insulin resistance. $(17,18)$ An aromatase deficient men had low sexual desire, which was improved by low doses of estrogen replacement.(19)

It would not be an exaggeration to state that the studies on aromatase-deficient or estrogenresistant individuals provided a full picture of the physiology of estrogen and uncovered previously unanticipated roles of estrogen in men. These observations and studies on humans were complemented by mechanism-based studies using mouse knockout models. Here we provide a summary of these developments over the past 2 decades.

\section{Consequences of Aromatase Deficiency during Pregnancy}

The earliest clinical signs of aromatase deficiency becomes manifest during pregnancy. A pregnant mother an aromatase-deficient fetus becomes severely virilized. An elaborate mechanism, which involves the fetal adrenal androgen production, altered placental steroid metabolism, maternal virilization and masculinization of a 46,XX fetus, accounts for these clinical signs. The pregnant mother has male levels of circulating testosterone and develops cystic acne, hirsutism and clitoromegaly, whereas the 46,XX fetus is born with severely masculinized external genitalia.

The placenta develops from trophectoderm of the blastocyst and is genetically, fetal tissue. Among mammalian placentae, the human placenta is uniquely capable of aromatizing massive quantities of androgens into estrogens most efficiently. In pregnant women at or near term, there is a daily production of 70 micromoles $(20 \mathrm{mg})$ of estradiol and $300-450$ micromoles (80-120 mg) of estriol.(20) During the third trimester of gestation, it is very common to detect maternal serum estradiol levels above the 100,000 picomole/L $(27,000$ $\mathrm{pg} / \mathrm{ml}$ ) and estriol levels above the 55,000 picomoles/L ranges.(20) The physiologic role of this massive placental estrogen production during pregnancy is not understood. However, when the aromatization capacity of the placenta is exceeded by the overproduction of 
androgenic steroids of maternal origin, e.g., by luteomas, during early pregnancy, virilization of the female fetus and the mother has been noted.(21) By contrast, serum estradiol (1053-1900 picomoles/L or 287-518 pg/ml) or estriol (134-2200 picomoles/L or $37-608 \mathrm{pg} / \mathrm{ml}$ ) levels in the third trimester were extremely low in the pregnant mothers of the infants with aromatase deficiency. $(4,14)$ Placental tissue from such a newborn with aromatase deficiency failed to convert precursor steroids into estrogens.(4) As a result, the androgen and estrogen precursor dehydroepiandrosterone sulfate (DHEAS) derived primarily from the fetal adrenal is converted in placenta to androstenedione and testosterone. Thus, both the female fetus and mother become virilized. Severe genital ambiguity noted in the female fetuses implies exposure of external genitalia to testosterone and dihydrotestosterone much earlier than 12th week of gestation. $(4,6,11,12,14,15,22)$

\section{Mutations and Phenotypes}

Estrogen biosynthesis is catalyzed by an enzyme located in the endoplasmic reticulum of estrogen producing cells. This enzyme is a member of the cytochrome P450 superfamily, namely aromatase, the product of the CYP19A1 gene.(23) Aromatase catalyzes the three precursors - androstenedione, testosterone and 16a-hydroxydehydroepiandrosterone sulfate (after conversion to 16a-hydroxyandrostenedione) - into estrone, estradiol and estriol, respectively.(24) In human, the CYP19A1 gene and its product aromatase are expressed in the ovary, testis, placenta, adipose tissue, skin, and the brain(25). Estrogen levels in the circulation are primarily maintained by aromatase activity in the ovarian granulosa cells of ovulatory women, and adipose tissue of men and postmenopausal women.(25)

The size of the aromatase gene is greater than $123 \mathrm{~kb}$, and its tissue-specific expression is regulated by the use of tissue-specific promoters involving alternative splicing. $(25,26)$ In spite of the size and complexity of the aromatase gene, thus far only a limited number of definitively characterized humans with aromatase deficiency have been reported as indicated above, although deficiencies of most other steroidogenic forms of P450 (17a-hydroxylase, $11 \beta$-hydroxylase, $21 \beta$-hydroxylase) have already been well-characterized. Examination of genomic DNA from the Japanese newborn girl revealed that a consensus splice acceptor site between the coding exon VI and intron VI was mutated, resulting in the use of a cryptic acceptor site further downstream in intron VI. $(4,5)$ This homozygous mutation added an insert of $87 \mathrm{bp}$ to arom mRNA resulting in translation of an abnormal protein with 29 extra amino acids.(5) This infant was born with severely virilized external genitalia.

The first case of female adolescent aromatase deficiency was described in an 18-year-old girl with primary amenorrhea and female pseudohermaphroditism.(6) She was found to be a compound heterozygote for two different missense mutations in the heme-binding region of the aromatase gene.(23) The first adult diagnosed with aromatase deficiency was a 24-yearold man.(15) He and her 28-year-old sister, both affected by aromatase deficiency, were found to have the same homozygous missense mutation in a highly-conserved region of the aromatase gene believed to guard the substrate access channel.(15) In this same region, another homozygous mutation was found in a 38-year-old Italian man.(7) These initial reports were followed by a number of publications describing aromatase deficiency in virilized newborn girls or unremarkable boys and/or their virilized mothers as a result of homozygous or compound heterozygous point mutations yielding frameshifts, nonsense codons or stop codons in the aromatase gene. $(11,13,14)$ In vitro transient expression of the aromatase cDNAs with missense mutations gave rise to only trace amounts of aromatase activity. These mutations in the aromatase gene in females have given rise to certain common phenotypic features, e.g., congenital genital ambiguity, pubertal failure, hypergonadotropic hypogonadism and multicystic ovaries. The male phenotype resulting from aromatase deficiency was similar in many aspects to the previously described case of 
ERa deficiency, namely tall stature with eunucoid body proportions and continued linear growth into adulthood due to incomplete epiphyseal closure, and osteoporosis. $(2,7,15)$ In 2013, Quaynor, et al, reported the second case of estrogen resistance, an 18 year-old adolescent girl without breast development and with markedly elevated serum estrogen levels and multicystic ovaries.(10) Both estrogen resistant patients had homozygous point mutations in the ERa gene. $(2,10)$

In 2007, Lin, et al, reported four 46,XX patients from 3 kindreds with variable degrees of androgenization and pubertal failure who were homozygous or compound heterozygous for point mutations, single codon deletions or in-frame deletions in the aromatase genes.(27) Aromatase cDNAs with a point mutation or a single codon deletion revealed low residual aromatase activity in the two cases in which variable degrees of breast development occurred. These observations led the authors to postulate that aromatase mutations can produce variable or "nonclassic" phenotypes in humans.(27)

\section{Natural and Experimental Animal Models}

The spotted hyena constitutes a natural animal model, in which certain features of aromatase deficiency in humans may be recapitulated.(16) Studies regarding steroid metabolism in the placenta of spotted hyena has increased our understanding of the mechanism whereby virilization of female spotted hyenas occurs in utero, which is a normal physiologic process in these animals.(16) The female spotted hyena is naturally born with fused labia to form a pseudoscrotum, and the clitoris is enlarged to form a male-like phallus through which the urogenital sinus traverses. Analogous to DHEAS of human fetal adrenal origin, extremely large quantities of an androgen precursor, namely androstenedione is produced by ovarian stroma during late-term pregnancy of the hyena. However, as in other nonprimates, aromatase activity of the spotted hyena placenta is very low compared with the human placenta.(16) The conversion of androstenedione to testosterone is efficiently carried out in spotted hyena placentae as in the human placenta.(16) Testosterone production by the spotted hyena placenta must start very early during the embryonic life in order to explain severe virilization of female external genitalia.

Although there are apparent similarities between female pseudohermaphroditism due to human aromatase deficiency and the naturally occurring in utero virilization of female spotted hyenas, there are profound differences between molecular mechanisms of androgenization and phenotypic features. First, the major precursor for testosterone in hyena placenta is androstenedione that is secreted in large quantities by maternal ovaries. In humans, DHEAS, a circulating precursor secreted by the fetal adrenal gland would primarily contribute to placental testosterone production in the absence of sufficient aromatase activity.(28) Secondly, the adult female spotted hyena can ovulate and reproduce, whereas aromatase-deficient women so far described are incapable of ovulating. This may in part be due to profound differences in ovarian physiology between these two species. Third, androgen excess during pregnancy of hyenas does not seem to be clinically detectable in already virilized mothers.

It has also been proposed that in utero androgen exposure of the female hyena causes depletion of the primordial follicles replaced by stroma.(16) Ovarian biopsy of an aromatase-deficient girl at 17 months of age revealed many closely packed primordial follicles, which was considered normal.(6) An aromatase-deficient adult woman underwent ovarian biopsy when she was 13, and excessive atresia of follicles was reported.(15) Rates of follicular atresia in aromatase-deficient women during various stages of development need to be clarified further. Therefore, the in utero virilization of female spotted hyenas and aromatase-deficient human females may appear related, however, the (patho)physiologic significance and the underlying molecular mechanisms are quite distinct. 
Studies on knockout mice lacking a functional aromatase enzyme (ArKO) or estrogen receptor-a (a-ERKO) provided tremendous opportunities to learn the physiologic roles of estrogen in mammals. $(29,30)$ Briefly, both ArKO and a-ERKO females revealed underdeveloped mammary tissue, external genitalia and uteri and were anovulatory with numerous large ovarian follicles.(29, 30) a-ERKO males were infertile primarily because of an interruption of fluid reabsorption by the head of the epididymis. This caused sperm to enter the epididymis diluted, rather than concentrated, resulting in infertility.(31) ArKO males were initially fertile, but developed progressive infertility, until their ability to sire pups was severely impaired.(32) It turned out that spermatogenesis in ArKO males because arrested at early spermiogenic stages from 4.5 months of age. This was accompanied by Leydig cell hyperplasia and hypertrophy, presumably as a consequence of increased circulating LH.(32) In summary, phenotypes of a-ERKO and ArKO males are indicative of critical roles of estrogen in sperm production and function. Because of extremely limited numbers of studies on men with mutations in P450arom or ERa genes, the functions of estrogen in male fertility are not well understood. $(2,7,15,19)$

\section{Clinical Presentation and Diagnosis}

First clinical signs of virilization in mothers of the majority of aromatase-deficient fetuses were noted during various stages of pregnancy. For example, virilization was recognized as early as at 12 and as late as 30 weeks gestation in the mothers of fetuses with aromatase deficiency. $(4,14,15)$ Signs and symptoms consist of severe acne, lowered voice, hirsutism and clitoromegaly. Androgen precursors of fetoplacental and maternal origin that do not become aromatized in placenta are converted to testosterone in placenta and possibly peripheral maternal tissues to cause maternal virilization. These symptoms gradually disappeared after delivery.

During the second half of pregnancy, extremely low maternal serum estradiol and estriol levels within the range of $0.1-8 \%$ of normal values will differentiate aromatase deficiency from virilizing maternal ovarian tumors or maternal ingestion of androgens. Low levels of estriol in maternal plasma or urine may also be detected in placental sulfatase deficiency and in the case of an anencephalic fetus.(20) However, in these conditions, maternal estriol or estradiol levels are not as low as in aromatase deficiency; testosterone is not elevated; and maternal virilization is absent. For differential diagnosis, one should rarely need to perform the DHEAS loading test. $(4,20)$

All affected girls are born with labioscrotal fusion and a greatly enlarged phallus with a single meatus at its base. Karyotype is 46,XX. Urogenitogram and sonographic examination of pelvis reveal the presence of a urogenital sinus, vagina and uterus. Lack of progressive virilization and normal basal or ACTH-stimulated 17a-hydroxyprogesterone, 11deoxycortisol and $\Delta 5 / \Delta 4$ steroid ratios rule out congenital virilizing adrenal hyperplasia. The lack of elevated testosterone response to hCG administration rules out a diagnosis of true hermaphroditism in an infant with ambigious genitalia due to aromatase deficiency.

During the first two years of lives of aromatase deficient girls, both basal and GnRHstimulated FSH levels (50 to 75 and 200 to $215 \mathrm{mIU} / \mathrm{ml}$, respectively) were far greater than in normal subjects, whereas estradiol and estrone were either too near to detection limit of radioimmunoassay or undetectable. $(6,14)$ Basal $\mathrm{LH}$ was normal or slightly elevated $(5-10$ $\mathrm{mIU} / \mathrm{ml}$ ) during infancy. Between ages 3 and 4 , an aromatase-deficient girl had persistently elevated serum FSH and LH levels and multicystic ovaries.(14) Oral estradiol (0.4 mg/day) treatment resulted in normalization of gonadotropin levels, regression of ovarian cysts and also increased bone mineral density in this girl.(14) At 8 years of age, serum FSH and LH levels of an aromatase-deficient adolescent girl were found to be in the normal (either undetectable or barely detectable) range. (6) Serum DHEAS, 17a-hydroxyprogesterone, 
androstenedione and testosterone were also found to be in the normal range during childhood. Aromatase-deficient girls grew and developed normally during infancy and childhood. $(6,15)$ However, at puberty, these girls did not experience breast development nor the normal growth spurt. They did develop acne, pubic and axillary hair, and further clitoral enlargement. Both ovaries were found to contain multiple large $(4-8 \mathrm{~cm})$ cysts. Large cystic ovaries were noted as early as at 2 years of age.(14) Basal FSH (16-75 mIU/ $\mathrm{ml})$, LH (17-18 $\mathrm{mIU} / \mathrm{ml})$, and testosterone $(3.3-5.2 \mathrm{nmol} / \mathrm{L})$ levels were elevated during puberty. Mild elevations were also noted in levels of androstenedione and 17ahydroxyprogesterone measured serially. $(6,15)$ Bone age was 8 months to 4 years behind chronological age at puberty. Two aromatase-deficient girls were started on oral estrogens indefinitely at the onset of puberty. Breast development and growth spurt ensued after estrogen replacement in both individuals. $(6,15)$ The final heights of both women were normal, although this may be a consequence of the estrogen replacement. $(6,15)$ It may be predicted that linear bone growth would have continued in the absence of estrogen replacement, as is the case with the aromatase-deficient men.

Two aromatase-deficient men went through an unremarkable pubertal development. $(7,15)$ Although their heights were regarded as normal at adolescence, the linear growth continued into adulthood. When first evaluated for aromatase deficiency, they were 24 and 38 years old, 204 and $190 \mathrm{~cm}$ tall, and both had severely retarded bone ages. Both had eunucoid body proportions. Diffuse bone demineralization and lack of epiphyseal fusion were detected by $\mathrm{x}$-ray films in the knees and pelvis. Conflicting findings in these two men were the presence of macroorchidism in one and microorchidism in the other. $(7,15)$ The aromatase-deficient man with microorchidism also suffered from infertility due to severe oligoasthenospermia, although his two brothers without aromatase gene defects were also found to have similar sperm problems.(7) It is possible, therefore, that the severely decreased sperm count and motility in this aromatase-deficient man may be due to a familial disorder other than aromatase deficiency.(7) LH, FSH and testosterone levels in both aromatase-deficient patients were markedly elevated. $(7,15)$ Fasting insulin and total and LDL cholesterol levels were increased, whereas HDL cholesterol was low. Despite evidence of insulin resistance, glucose levels were normal. Estrogen administration lowered insulin levels.(15) Table 1 lists the prominent clinical features of aromatase deficiency. Useful laboratory tests for diagnosis are included in Table 2.

\section{Summary}

The observations on aromatase deficient humans suggested that estrogen of fetoplacental origin is not necessary for successful implantation or embryonic or fetal development, as once believed. Whether or not maternally-derived estrogen is necessary or can substitute is not known at this time. On the other hand, aromatase expression in human placenta appears to be necessary for the clearance of DHEAS from fetal and maternal adrenals by conversion into estrogens. Otherwise, placental sulfatase, $3 \beta$-hydroxysteroid dehydrogenase $\Delta^{4-5}$. isomerase and $17 \beta$-hydroxysteroid dehydrogenase enzymes have the capacity to convert this precursor into testosterone. This results in sufficiently high testosterone production to create severe masculinization of female external genitalia in early embryonic life as well as virilization of the mother.

The observations on patients with aromatase deficiency clarified the role of estrogen in the sex steroid-gonadotropin feedback mechanism. Serum gonadotropins were markedly elevated during the first few years of life of aromatase-deficient girls emphasizing the negative feedback role of ovarian estrogen during this period. Persistently elevated gonadotropins and large ovarian cysts were documented between the ages 2 and 4 suggesting an important role of estrogen, albeit in very low serum levels, in maintaining the gonadostat.(14) In some aromatase-deficient men, elevated concentrations of serum FSH 
and LH despite the high testosterone levels supports an important negative feedback role of estrogen either of peripheral origin or synthesized locally in the brain from androgens or from both sources in the regulation of FSH and LH.(15, 33-35) In fact, levels of serum gonadotropins and testosterone decreased after low-dose estrogen replacement in an aromatase-deficient man.(7)

High levels of gonadotropins in the absence of estrogen in aromatase-deficient girls gave rise to formation of multiple large ovarian cysts that resolved with estrogen replacement therapy. $(6,14,15)$ The ovarian biopsy result from one of the aromatase deficient girls at puberty was reported to be consistent with a polycystic ovary.(6) Comparable histologic features were found in the ovaries of a-ERKO mice.(29) Ovaries of ArKO or a-ERKO adult mice showed multiple cystic follicles but no evidence of ovulation.(29, 30) Thus, estrogen action appears to be necessary for normal cyclic follicular development by way of regulating gonadotropin secretion. Aromatase deficiency or estrogen resistance, however, do not prevent uncontrolled follicular growth, which seems to be mediated primarily by gonadotropins. $(29,30)$

The possible impact of lack of estrogen representation in the brain on psychosexual development of both women and men with aromatase deficiency was considered by two groups of authors $(2,6,7,15,19,36)$ It appears that estrogen deficiency may decrease libido of these men. $(19,36)$

The striking consequences of the lack of estrogen on bone maturation and turnover were demonstrated in the two extremely tall and aromatase-deficient men with eunucoid proportions and are similar to those recently described in the estrogen-resistant man.(2, 7, $13,15,17,37,38)$ Epiphyseal fusion and maintenance of bone mass appear to be two obvious, but until now, unrecognized consequences of estrogen action in men. $(2,7,13,15$, $17,37,38)$ Estrogens have been shown to exert their effects on osteoblasts and osteoclasts through regulation of cytokine expression in the bone. $(39,40)$ It is remarkable to note that such low plasma concentrations of estrogen that are ordinarily found in normal men may sufficiently suppress the expression of osteoporotic cytokines in the bone. The physiologic role of local production of estrogen within bone cells is not known as yet. A synergistic role of testosterone or its potent androgenic metabolite dihydrotestosterone at levels found in adult men in this antiresorptive action of estrogen is very likely. Bone density was increased in aromatase-deficient men upon estrogen administration, and similarly, insulin resistance improved.(41) This is consistent with the similar decrease in basal insulin levels in postmenopausal women treated with transdermal estradiol.(42) On the other hand, the estrogen-resistant man showed biochemical evidence of both insulin resistance and glucose intolerance that did not respond to very high doses of estrogen, as expected.(2) Although the mechanism of insulin resistance in aromatase deficiency is not known, it is not likely to be caused by elevated testosterone, because the estrogen-resistant man had a much more severe degree of insulin resistance despite normal serum testosterone. $(2,15)$ As noted above, the possible association of aromatase deficiency with abnormal testicular size and low sperm count and motility has not been resolved yet. Normal sperm count but low motility noted in the estrogen-resistant man are suggestive of male infertility as another symptom associated with deficient estrogen action.(2) The causal relationship of estrogen deficiency with severe oligo-asthenospermia found in an aromatase-deficient man is not clear at this time(7)

The regulation of lipoprotein synthesis seems to be another crucial role of estrogens in men. (43) Aromatase inhibitor treatment of normal men was observed to decrease serum HDL cholesterol levels. Abnormally low HDL/LDL cholesterol ratio in an aromatase-deficient man emphasizes this critical role of estrogen action in men, which is the prevention of 
cardiovascular disease.(15) In fact, this abnormal lipid profile was partially reversed by estrogen replacement in another aromatase deficient man.(7)

Certain aromatase gene mutations may cause milder degrees of aromatase deficiency analogous to other steroidogenic P450 defects, e.g., nonclassical 21-hydroxylase deficiency. (27) These may give rise to a whole host of symptoms with varying degrees of severity, such as polycystic ovaries and incomplete pubertal development in women, and infertility, insulin resistance, tallness with eunucoid proportions and tendency to develop cardiovascular disease in both men and women. As another twist, since tissue-specific expression of the aromatase gene is regulated in part by use of tissue-specific promoters, mutations in any of these promoter regions or splice-junctions may result in loss of estrogen formation in one organ only, e.g., placenta, ovary, brain or adipose tissue.(25) Analysis of such cases would provide insight into the relative role of estrogens produced in each of these sites. Ready availability of whole genome sequencing may facilitate discovering these possibilities.

\section{Clinical Management}

In aromatase-deficient girls, estrogen replacement is directed towards maintaining the bone mineral density and preventing formation of ovarian cysts during early childhood, and later, inducing growth spurt, breast development and periods at the expected time of puberty.(6, 15) Thus, continuous estrogen replacement immediately after infancy should be administered judiciously, and bone age and signs of premature breast development should be monitored very closely. Estrogen replacement may be started as early as at 2 years of age using the lowest possible estrogen dose that will prevent formation of ovarian cysts but not cause premature breast development or accelerated bone age. Oral conjugated estrogens $(0.15 \mathrm{mg} /$ day, or every other day) or micronized estradiol $(0.25 \mathrm{mg} /$ day, or every other day) may be used, and the dose may be titrated to maintain the suppression of FSH and LH. The dose of conjugated estrogens should be raised to $0.3 \mathrm{mg} /$ day at the chronological age of 1012 (or bone age of 11) to initiate secondary sexual characteristics. The goals at this stage of replacement are to initiate breast development and growth spurt. After a year of treatment, the dose of conjugated estrogens may be gradually increased over the next 2 years to 0.625 to $1.25 \mathrm{mg}$ daily depending on the response to treatment. From the second year on, a progestin, e.g., medroxyprogesterone acetate, 5 to $10 \mathrm{mg} / \mathrm{day}$, should be given during the first 10 days of each month to imitate menses and prevent endometrial hyperplasia. By age 14 , all aromatase-deficient girls may be switched to a combination oral contraceptive containing $20-35 \mu \mathrm{g}$ of ethinyl estradiol for adequate pituitary suppression and estrogen replacement.

In aromatase-deficient men, estrogen replacement should give rise to circulating estradiol levels that are sufficient to ensure epiphyseal closure, normal lipid profile and insulin levels, and maintenance of bone mass but not excessive such as to cause gynecomastia. Estrogen replacement should also restore the serum gonadotropin and testosterone levels to normal. One should start with the lowest possible estrogen dose that will achieve these effects. Transdermal estradiol may be started at $12.5-25$ mcg twice weekly. (44) If diagnosis is made early, the lowest possible dose of estrogen should be given during late puberty when adult levels of testosterone are observed in order to prevent gynecomastia. Thus, replacement may be started approximately at ages 14-16 or thereafter at the time of diagnosis. Replacement should be continued indefinitely. If the levels of gonadotropins and testosterone are not normalized after 6 months of treatment, the dose of transdermal estradiol may be raised incrementally. These men should also be closely monitored for epiphyseal closure, bone density, serum cholesterol and development of gynecomastia during estrogen replacement. Estrogen replacement to restore sexual desire is another 
potential indication. There is sparse data to guide the clinician for this indication; thus, such treatment should be individualized at this time. $(19,36)$

\section{Acknowledgments}

Preparation of this article was supported in part by a grant from the National Institute of Child Health and Development (R37-HD38691).

\section{References}

1. Deroo BJ, Korach KS. Estrogen receptors and human disease. J Clin Invest. 2006; 116:561-70. [PubMed: 16511588]

2. Smith EP, Boyd J, Frank GR, Takahashi H, Cohen RM, Specker B, et al. Estrogen resistance caused by a mutation in the estrogen-receptor gene in a man. The New England journal of medicine. 1994; 331:1056-61. [PubMed: 8090165]

3. Smith EP, Specker B, Korach KS. Recent experimental and clinical findings in the skeleton associated with loss of estrogen hormone or estrogen receptor activity. J Steroid Biochem Mol Biol. 2010; 118:264-72. [PubMed: 19900547]

4. Shozu M, Akasofu K, Harada T, Kubota Y. A new cause of female pseudohermaphroditism: placental aromatase deficiency. J Clin Endocrinol Metab. 1991; 72:560-6. [PubMed: 1825497]

5. Harada N, Ogawa H, Shozu M, Yamada K, Suhara K, Nishida E, et al. Biochemical and molecular genetic analyses on placental aromatase (P-450AROM) deficiency. J Biol Chem. 1992; 267:4781-5. [PubMed: 1371509]

6. Conte FA, Grumbach MM, Ito Y, Fisher CR, Simpson ER. A syndrome of female pseudohermaphrodism, hypergonadotropic hypogonadism, and multicystic ovaries associated with missense mutations in the gene encoding aromatase (P450arom). J Clin Endocrinol Metab. 1994; 78:1287-92. [PubMed: 8200927]

7. Carani C, Qin K, Simoni M, Faustini-Fustini M, Serpente S, Boyd J, et al. Effect of testosterone and estradiol in a man with aromatase deficiency. The New England journal of medicine. 1997; 337:915. [PubMed: 9211678]

8. Jones ME, Boon WC, Proietto J, Simpson ER. Of mice and men: the evolving phenotype of aromatase deficiency. Trends Endocrinol Metab. 2006; 17:55-64. [PubMed: 16480891]

9. Grumbach MM. Aromatase deficiency and its consequences. Adv Exp Med Biol. 2011; 707:19-22. [PubMed: 21691947]

10. Quaynor SD, Stradtman EW Jr, Kim HG, Shen Y, Chorich LP, Schreihofer DA, et al. Delayed puberty and estrogen resistance in a woman with estrogen receptor alpha variant. The New England journal of medicine. 2013; 369:164-71. [PubMed: 23841731]

11. Portrat-Doyen SFM, Nicolino M, Morel Y, Chatelain PC. Female pseudohermaphroditism (FHP) resulting from aromatase (P450arom) deficiency associated with a novel mutation (R457) in the CYP19 gene. Horm Res. 1996; 46:7.

12. Ludwig M, Beck A, Wickert L, Bolkenius U, Tittel B, Hinkel K, et al. Female pseudohermaphroditism associated with a novel homozygous G-to-A (V370-to-M) substitution in the P-450 aromatase gene. J Pediatr Endocrinol Metab. 1998; 11:657-64. [PubMed: 9829218]

13. Deladoey J, Fluck C, Bex M, Yoshimura N, Harada N, Mullis PE. Aromatase deficiency caused by a novel P450arom gene mutation: impact of absent estrogen production on serum gonadotropin concentration in a boy. J Clin Endocrinol Metab. 1999; 84:4050-4. [PubMed: 10566648]

14. Mullis PE, Yoshimura N, Kuhlmann B, Lippuner K, Jaeger P, Harada H. Aromatase deficiency in a female who is compound heterozygote for two new point mutations in the P450arom gene: impact of estrogens on hypergonadotropic hypogonadism, multicystic ovaries, and bone densitometry in childhood. J Clin Endocrinol Metab. 1997; 82:1739-45. [PubMed: 9177373]

15. Morishima A, Grumbach MM, Simpson ER, Fisher C, Qin K. Aromatase deficiency in male and female siblings caused by a novel mutation and the physiological role of estrogens. J Clin Endocrinol Metab. 1995; 80:3689-98. [PubMed: 8530621] 
16. Yalcinkaya TM, Siiteri PK, Vigne JL, Licht P, Pavgi S, Frank LG, et al. A mechanism for virilization of female spotted hyenas in utero. Science. 1993; 260:1929-31. [PubMed: 8391165]

17. Maffei L, Murata Y, Rochira V, Tubert G, Aranda C, Vazquez M, et al. Dysmetabolic syndrome in a man with a novel mutation of the aromatase gene: effects of testosterone, alendronate, and estradiol treatment. J Clin Endocrinol Metab. 2004; 89:61-70. [PubMed: 14715828]

18. Rochira V, Madeo B, Zirilli L, Caffagni G, Maffei L, Carani C. Oestradiol replacement treatment and glucose homeostasis in two men with congenital aromatase deficiency: evidence for a role of oestradiol and sex steroids imbalance on insulin sensitivity in men. Diabet Med. 2007; 24:1491-5. [PubMed: 17976198]

19. Carani C, Rochira V, Faustini-Fustini M, Balestrieri A, Granata AR. Role of oestrogen in male sexual behaviour: insights from the natural model of aromatase deficiency. Clin Endocrinol (Oxf). 1999; 51:517-24. [PubMed: 10583321]

20. Casey, ML.; MacDonald, PC.; Simpson, ER. Endocrinological changes of pregnancy. In: Foster, DW.; Wilson, JD., editors. Williams Textbook of Endocrinology. Philadelphia, PA: W.B. Saunders; 1992. p. 977-92.

21. Verkauf BS, Reiter EO, Hernandez L, Burns SA. Virilization of mother and fetus associated with luteoma of pregnancy: a case report with endocrinologic studies. Am J Obstet Gynecol. 1977; 129:274-80. [PubMed: 197851]

22. Grumbach MM, Ducharme JR. The effects of androgens on fetal sexual development: androgeninduced female pseudohermaphrodism. Fertil Steril. 1960; 11:157-80. [PubMed: 13829839]

23. Simpson ER, Mahendroo MS, Means GD, Kilgore MW, Hinshelwood MM, Graham-Lorence S, et al. Aromatase cytochrome P450, the enzyme responsible for estrogen biosynthesis. Endocr Rev. 1994; 15:342-55. [PubMed: 8076586]

24. Corbin CJ, Graham-Lorence S, McPhaul M, Mason JI, Mendelson CR, Simpson ER. Isolation of a full-length cDNA insert encoding human aromatase system cytochrome P-450 and its expression in nonsteroidogenic cells. Proc Natl Acad Sci U S A. 1988; 85:8948-52. [PubMed: 2848247]

25. Bulun SE, Lin Z, Imir G, Amin S, Demura M, Yilmaz B, et al. Regulation of aromatase expression in estrogen-responsive breast and uterine disease: from bench to treatment. Pharmacological reviews. 2005; 57:359-83. [PubMed: 16109840]

26. Demura M, Martin RM, Shozu M, Sebastian S, Takayama K, Hsu WT, et al. Regional rearrangements in chromosome $15 \mathrm{q} 21$ cause formation of cryptic promoters for the CYP19 (aromatase) gene. Human molecular genetics. 2007; 16:2529-41. [PubMed: 17584767]

27. Lin L, Ercan O, Raza J, Burren CP, Creighton SM, Auchus RJ, et al. Variable phenotypes associated with aromatase (CYP19) insufficiency in humans. J Clin Endocrinol Metab. 2007; 92:982-90. [PubMed: 17164303]

28. Siiteri PK, MacDonald PC. Placental estrogen biosynthesis during human pregnancy. J Clin Endocrinol Metab. 1966; 26:751-61. [PubMed: 4223909]

29. Lubahn DB, Moyer JS, Golding TS, Couse JF, Korach KS, Smithies O. Alteration of reproductive function but not prenatal sexual development after insertional disruption of the mouse estrogen receptor gene. Proc Natl Acad Sci U S A. 1993; 90:11162-6. [PubMed: 8248223]

30. Fisher CR, Graves KH, Parlow AF, Simpson ER. Characterization of mice deficient in aromatase (ArKO) because of targeted disruption of the cyp19 gene. Proc Natl Acad Sci U S A. 1998; 95:6965-70. [PubMed: 9618522]

31. Hess RA, Bunick D, Lee KH, Bahr J, Taylor JA, Korach KS, et al. A role for oestrogens in the male reproductive system. Nature. 1997; 390:509-12. [PubMed: 9393999]

32. Robertson KM, O’Donnell L, Jones ME, Meachem SJ, Boon WC, Fisher CR, et al. Impairment of spermatogenesis in mice lacking a functional aromatase (cyp 19) gene. Proc Natl Acad Sci U S A. 1999; 96:7986-91. [PubMed: 10393934]

33. Bagatell CJ, Dahl KD, Bremner WJ. The direct pituitary effect of testosterone to inhibit gonadotropin secretion in men is partially mediated by aromatization to estradiol. J Androl. 1994; 15:15-21. [PubMed: 8188534]

34. Finkelstein JS, O'Dea LS, Whitcomb RW, Crowley WF Jr. Sex steroid control of gonadotropin secretion in the human male. II. Effects of estradiol administration in normal and gonadotropinreleasing hormone-deficient men. J Clin Endocrinol Metab. 1991; 73:621-8. [PubMed: 1908485] 
35. Rochira V, Carani C. Aromatase deficiency in men: a clinical perspective. Nature reviews Endocrinology. 2009; 5:559-68.

36. Carani C, Granata AR, Rochira V, Caffagni G, Aranda C, Antunez P, et al. Sex steroids and sexual desire in a man with a novel mutation of aromatase gene and hypogonadism.

Psychoneuroendocrinology. 2005; 30:413-7. [PubMed: 15721053]

37. Maffei L, Rochira V, Zirilli L, Antunez P, Aranda C, Fabre B, et al. A novel compound heterozygous mutation of the aromatase gene in an adult man: reinforced evidence on the relationship between congenital oestrogen deficiency, adiposity and the metabolic syndrome. Clin Endocrinol (Oxf). 2007; 67:218-24. [PubMed: 17547681]

38. Lanfranco F, Zirilli L, Baldi M, Pignatti E, Corneli G, Ghigo E, et al. A novel mutation in the human aromatase gene: insights on the relationship among serum estradiol, longitudinal growth and bone mineral density in an adult man under estrogen replacement treatment. Bone. 2008; 43:628-35. [PubMed: 18590994]

39. Horowitz MC. Cytokines and estrogen in bone: anti-osteoporotic effects. Science. 1993; 260:6267. [PubMed: 8480174]

40. Jilka RL, Hangoc G, Girasole G, Passeri G, Williams DC, Abrams JS, et al. Increased osteoclast development after estrogen loss: mediation by interleukin-6. Science. 1992; 257:88-91. [PubMed: 1621100]

41. Bilezikian JP, Morishima A, Bell J, Grumbach MM. Increased bone mass as a result of estrogen therapy in a man with aromatase deficiency. The New England journal of medicine. 1998; 339:599-603. [PubMed: 9718379]

42. Cagnacci A, Soldani R, Carriero PL, Paoletti AM, Fioretti P, Melis GB. Effects of low doses of transdermal 17 beta-estradiol on carbohydrate metabolism in postmenopausal women. J Clin Endocrinol Metab. 1992; 74:1396-400. [PubMed: 1317387]

43. Bagatell CJ, Knopp RH, Rivier JE, Bremner WJ. Physiological levels of estradiol stimulate plasma high density lipoprotein2 cholesterol levels in normal men. J Clin Endocrinol Metab. 1994; 78:855-61. [PubMed: 8157711]

44. Rochira V, Faustini-Fustini M, Balestrieri A, Carani C. Estrogen replacement therapy in a man with congenital aromatase deficiency: effects of different doses of transdermal estradiol on bone mineral density and hormonal parameters. J Clin Endocrinol Metab. 2000; 85:1841-5. [PubMed: 10843162] 
Table 1

Clinical Features of Aromatase Deficiency

\begin{tabular}{|c|c|c|}
\hline & Female & Male \\
\hline Fetal life: & Masculinization of the mother during pregnancy & Masculinization of the mother during pregnancy \\
\hline Genitalia at birth: & Severe clitoromegaly and posterior labioscrotal fusion & Normal male \\
\hline Childhood: & Multi-cystic ovaries & Unremarkable \\
\hline Puberty: & $\begin{array}{l}\text { Absent growth spurt } \\
\text { Absent breast development } \\
\text { Primary amenorrhea } \\
\text { Further enlargement of clitoris } \\
\text { Enlarged cystic ovaries } \\
\text { Normal development of pubic and axillary hair }\end{array}$ & $\begin{array}{l}\text { Absent growth spurt } \\
\text { Normal pubertal development }\end{array}$ \\
\hline Adult: & $\begin{array}{l}\text { Severe estrogen deficiency } \\
\text { Virilization } \\
\text { Enlarged cystic ovaries } \\
\text { Continued linear bone growth }\end{array}$ & $\begin{array}{l}\text { Tall, eunucoid proportions with continued linear growth into } \\
\text { adulthood } \\
\text { Osteoporosis } \\
\text { Genu valgum }\end{array}$ \\
\hline
\end{tabular}


Table 2

Key Laboratory Findings in Aromatase Deficiency

\begin{tabular}{ll}
\hline Mother (pregnant woman): & $\begin{array}{l}\text { Severely low maternal serum estradiol and estriol } \\
\text { Remarkably elevated maternal serum testosterone }\end{array}$ \\
Infancy/Early Childhood (girls): & $\begin{array}{l}\text { Elevated FSH and undetectable serum estradiol } \\
\text { Multi-cystic ovaries (ultrasound) }\end{array}$ \\
Puberty (girls): & Multi-cystic ovaries (ultrasound) \\
& Retarded bone age \\
& Markedly elevated FSH and LH \\
& Mildly elevated levels of testosterone and androstenedione \\
& Undetectable estrone or estradiol in serum \\
& Elevated FSH, LH or testosterone \\
& Retarded bone age with unfused epiphyses \\
Ddult (men): & Densitometric and biochemical evidence of osteoporosis \\
& Elevated basal insulin level \\
& Decreased HDL/LDL cholesterol ratio \\
& ? Abnormal sperm count or function \\
\hline
\end{tabular}

